\title{
Modelling the spatial organization of land use in a farming territory. Example of a village in the Plateau Lorrain
}

\author{
Florence Le Ber ${ }^{\mathrm{u}^{*}, * *}$, Marc Benoît ${ }^{\mathrm{b}}$ \\ anra Liab, forêt d'Amance, 54280 Champenoux, France \\ ' Inra Sad, domaine du Joly, 88500 Mirecourt, France
}

(Received 17 June 1997, accepted 18 February 1998)

\begin{abstract}
We present a model which describes the spatial organization of land use in a farming territory and which produces maps of land use. The model is defined at the village scale in French regions with grouped settlements and mostly with mixed crop-livestock farming systems. It is based on qualitative agronomical rules which define how land is used depending on the characteristics of the territory (soil, slope, distance to settlement), the constraints on land-use categories and the needs and priorities of the considered farming systems. The model was implemented in C. Several farming systems were described, according to a typology of farming systems in the north-east of France. We show an example of the results from this model: a village of the Plateau Lorrain. (ㅇ Inra/Elsevier, Paris.)
\end{abstract}

spatial modelling / land-use management / dairy farms / artificial intelligence / rule-based model

Résumé - Un modèle d'organisation spatiale de l'occupation d'un territoire agricole : cas d'un village sur le plateau lorrain. Nous présentons un modèle d'organisation de l'occupation d'un territoire agricole qui produit des cartographies des utilisations du sol. Ce modèle est défini à l'échelle du territoire villageois, en région d'habitat groupé où les systèmes de polyculture-élevage sont dominants. Il est fondé sur une base de règles agronomiques, qui décrivent la localisation des occupations du sol nécessaires à un système de production, en fonction des caractéristiques du terrain (pente, sol et distance au bâti), des contraintes sur les occupations du sol et des priorités du système de production. Le modèle a été implanté en $\mathrm{C}$ et différents systèmes de production, issus d'une typologie réalisée dans le nord-est de la France ont été représentés. Un exemple d'utilisation du modèle est décrit pour un village du plateau lorrain. (ㅇ Inra/Elsevier, Paris.)

modélisation spatiale / assolement / élevage laitier / intelligence artificielle / modèle à base de règles

Communicated by Peter A. Finke (Wageningen)

* Correspondence and reprints

E-mail: leber@nancy.inra.fr.

** Associated to Loria UMR 7503, campus universitaire, BP 239, 54506 Vandœuvre-lès-Nancy cedex, France 


\section{INTRODUCTION}

Today, farm enterprises disappear or modify their farming systems and the surface of land which is free for rent or selling increases continuously. Moreover, land use changes. These changes can induce many problems, such as pollution [10], erosion [1] and landscape changes [7]. Understanding the organization of farming territories and their dynamics is necessary for predicting these problems and developing techniques or new farm management methods to solve them.

We therefore propose a rule-based model of the organization of agricultural territories: rules concern the way land use is allocated to a territory. The model was defined and implemented in a computer system. It was applied to field data. This model assumes simplifications which ensure that it can be used at a large scale. The base of rules contains knowledge about current farming systems and their physical and technical constraints. Other rules can easily be added into the base to take new constraints into consideration, as has been done in the CROPS system [5, 20].

This paper contains five sections. The first section describes our model and related work. The second and third sections present the rule bases of the model and the way it is used to obtain maps of agricultural territories. The data necessary are also described. The fourth section shows the implementation of the model. Some results are described and discussed in the fifth section. Finally, we present a conclusion and some future studies.

\section{A 'KOLKHOZIAN' MODEL OF AGRICULTURAL TERRITORIES}

The model has been defined during the development of an expert system for agricultural landscape analysis [13]. It comes from a cooperative model building process between an agronomist and a knowledge engineer. It concerns the spatial organization of land use in farming systems at the village scale.
This scale was chosen for various reasons: first, there are landscape patterns which have already been described at the village scale in certain French regions $[4,6]$. This means that, in these regions, this scale is significant for the organization of agricultural systems. Second, this scale is interesting since it lies between the farm enterprise scale, which has already been extensively studied, and the region scale, where many sources of information exist, such as satellite data. Moreover, this scale is the usual scale for statistical studies.

The name kolkhozian was chosen because of a major assumption that underlies our model: we considered that the village territory is occupied by a single farm system that may be a combination of real farm systems. We did not take into account the information about parcels and private property (which parcel belongs to which farm enterprise).

Our aim was to build a model that can be used upon various village territories with as little information as possible. We use map information (soil, topography, village location) and the information about the real farming system types in the villages. In this way our model was made to differ from statisticial models [19] which produce fine simulations of land-use organization but need information about parcel ownership.

The kolkhozian model is a rule-based model. The rules were defined from the agronomist's knowledge on how farmers organize the location of land use in a farm [3]. It is quite similar to the model described by Maxime et al. [15], except that the latter is based on direct surveys of farmers. Both models aim at describing the farmers' choices in order to understand them and to forecast variations. In this way they can be distinguished from the CROPS model $[5,20]$ whose aim is to optimize the use of a farm territory according to a set of constraints.

Finally our aim was to define a simple model. Therefore, we decided to first model 'simple' farming systems. We consequently chose the northeast of France, where farming systems are mainly mixed crop-livestock systems and where the settlements are grouped. We considered a farming system described by its production and production 
methods. It occupied the whole territory of a village. Farm buildings are inside the village. Crops and pastures are located according to the priorities of the system, the constraints of the crops and pastures and the characteristics of the territory.

\section{RULE BASES}

A qualitative description of our model is presented. First, we describe the characteristics of the territory, then those of farm systems and finally the constraints and preferences of land-use categories.

\subsection{Territory characteristics}

The territory of a village is defined by geometric rules: we assume that the limit between two neighbouring village territories is halfway between the two villages. This assumption is supported by the characteristics of mixed crop-livestock systems. It has been previously used to analyse farming systems from satellite data [14].

The territory can be divided into zones according to the local values of the following characteristics [17]:

1) slope: steep slopes prevent the use of agricultural machines;

2) soil: soil quality influences the yield of crops and pastures; it also prevents some technical operations during certain periods;

3) distance to village: it is important for the animals (dairy cows) but also for the ensilage of corn or grass;

4) distance to forest: the proximity of a forest can be useful for pastures, but has negative effects on crops (shadow, humidity, game damage);

5) accessibility from the village: forests and major roads lengthen the distance to the village.

\subsection{Characteristics of farming systems}

We define a village farming system as a combination of several enterprise farming systems which are used in the same village territory. A village farming system can be homogeneous, if all enterprise systems are of the same type, or heterogeneous. In the latter case we need rules to combine farming systems and describe how they share a territory. In the following paragraphs we only deal with homogeneous village farming systems, which are directly defined from the enterprise farming systems.

The enterprise farming systems of the north-east of France are grouped into several types from which we retained three types of mixed crop-livestock systems. The location of these types is strongly related to the characteristics of the territory (soil and relief): according to these characteristics, the farmer has either pastures and cereals on their own, or with corn or with corn and cash crops. All the farming system types of the northeast of France are described in Perrot [18].

LFR type (no corn nor cash crops): about $75 \%$ of the surface is pasture and about $25 \%$ cereals. Hay and cereal production is used to feed milk and beef cattle (beef steers).

LMI type (corn but no cash crops): hay, com and cereal production is used to feed milk cattle and baby beefs; the area is given over to pastures $(50 \%$ of the surface), cereals ( $25 \%)$ and corn (25\%).

LC type (corn and cash crops): milk, cereals and rape production. Half of the agricultural area is given over to cash crops; the remaining area is used as in LMI: about $50 \%$ of the area is taken up with cash crops, $25 \%$ with pastures and $25 \%$ with both corn and cereals for animal feeding.

These types are mean types which have been defined for two French departments in the north-east of France. In the following paragraphs we will adapt the types to a particular region which is the 'Plateau Lorrain'. For instance, the LMI type of the 'Plateau Lorrain' has less corn and cereals and more pastures than the mean LMI type (see section 6).

\subsection{Constraints and preferences of the land-use categories}

The main land-use categories of the previously described farming systems are as follows. 
Dairy cow pastures: these must be located near the village ( $1 \mathrm{~km} \max )$, there should be no obstacle (road) between the village and pastures; the minimal surface is $1 / 2$ ha. The year-round stocking rate is about $1.3 \mathrm{UGB} / \mathrm{ha}$ (UGB [unité gros bovin] is a French unit for counting animals).

Pastures for heifers and steers: these are best located near the forests and sheltered from the wind. The year-round stocking rate is about 0.7 UGB/ha.

Hay meadows: these should not be located near forests, the slope must be less than $15 \%$. These meadows can also be used as pastures.

Silage meadows: these must be located near the village ( $2 \mathrm{~km} \max$ ). The minimal surface is 1.5 ha. These meadows generally have two cuttings.

Crops: they grow better on limestone (calcareous soils), they should not be located near big forests (10 ha or more), corn must be near the village $(2 \mathrm{~km} \max )$, the other crops can be located further away $(15 \mathrm{~km} \max )$. The minimal surface is 1.5 ha and the slope must be less than $10 \%$.

In our model, constraints and preferences are considered only if the necessary data are available. For instance, minimal surfaces can be used since the territory is divided into parcels according to its characteristics (see section 4.1).

\section{DATA AND REASONING}

\subsection{Determining homogeneous soil-technical parcels}

The data on the Plateau Lorrain consist of a numerical model of the territory (IGN) and a soil map (1/25 000, CNRS) [8 ]. We took as an example the village of Lignéville which is located directly south of Vittel. The territory of Lignéville was defined according to the 'halfway rule' (see section 3.1).

Using the soil map, we draw up six classes:

TS: brown soils on Vittel dolomite, depth > $60 \mathrm{~cm}$;
TI: brown soils on Vittel dolomite, depth $<60 \mathrm{~cm}$;

TH: brown soils on alluvial and colluvial deposits;

G1: brown soils on ceratite limestone, slightly stony;

G2: brown soils on ceratite limestone, stony;

G3: brown soils on ceratite limestone, very stony.

The resulting map is shown in figure $l$ for the territory of Lignéville.

Using the numerical territory data we distinguished two slope classes: the first class included surfaces with a slope of less than $10 \%$, and the second class those with more than $10 \%$. Nowhere in the area was the slope more than $15 \%$.

In addition, we used satellite data to obtain the location and area of villages and forests [2].

Finally we set up distance classes. Each class covered $500 \mathrm{~m}$. The maximum distance from the village was about $4 \mathrm{~km}$ (see figure 2).

Using the three class maps (soil, slope, distance), we can determine homogeneous soil-technical parcels (figure 2): a homogeneous soil-technical parcel is a parcel with the maximum surface belonging to one class for all three criteria: soil, slope and distance. Then, each parcel is labelled according to its distance to the forest: there are two classes of parcels, those which are connected to the forest and those which are not. For the moment we do not take into account the criterium of accessibility, because of a lack of data (roads).

According to the resulting map of homogeneous soil-technical parcels we observe that a few criteria and a few classes for each criterium (six soil classes, two slope classes and seven distance classes) already lead to a complex situation: in our example there are 148 parcels (omitting the parcels smaller than 0.9 ha, which are too small for agricultural use; the total area of these parcels represents less than $5 \%$ of the territory area in our example). This level of complexity requires a complicated reasoning system. 


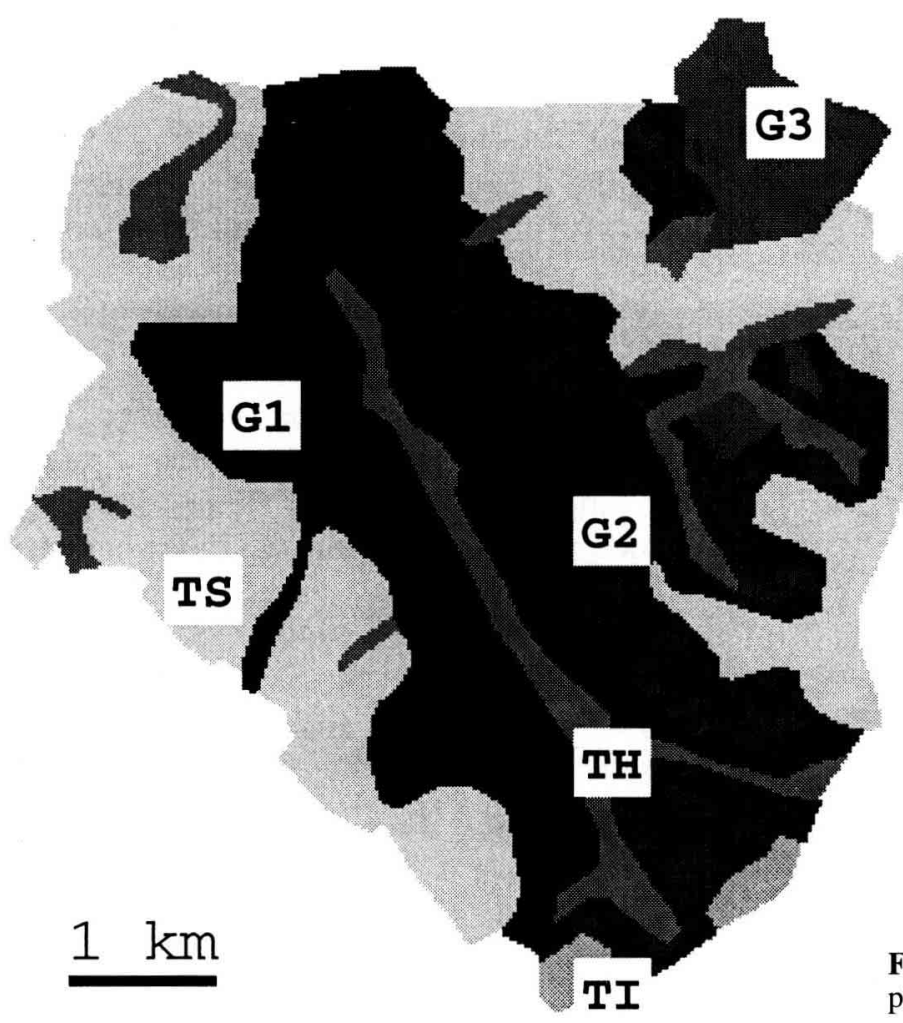

Figure 1. Soil map with six classes. Lignéville territory, Vittel plateau.

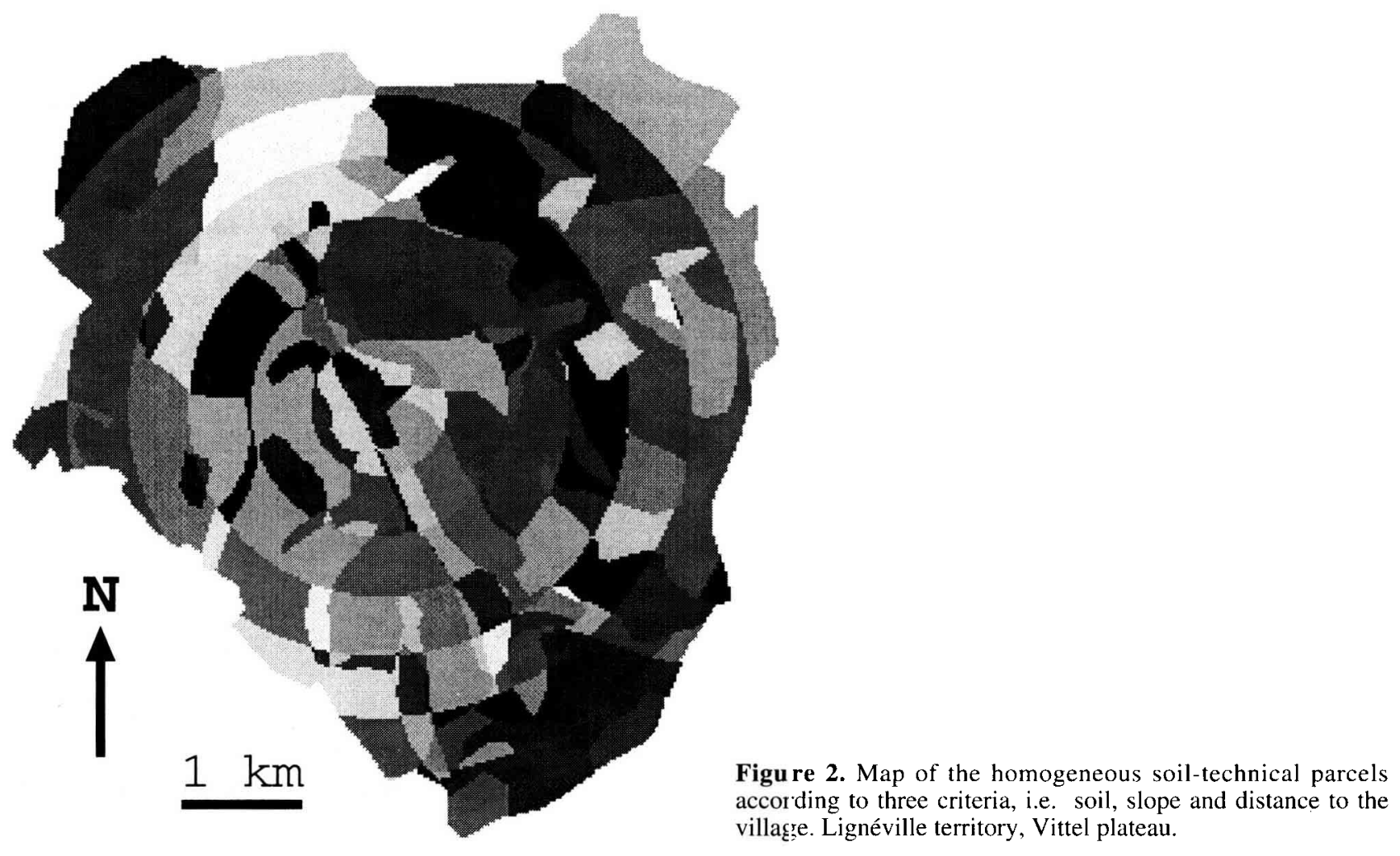

according to three criteria, i.e. soil, slope and distance to the villagge. Lignéville territory, Vittel plateau. 


\subsection{Reasoning}

The land-use map of a farming system is drawn up according to the priorities of the system. The priorities are based on the system itself and on the characteristics of the territory. Assuming that the settlements are grouped together, the major constraint generally concerns the proximity to settlements. The first priority of livestock systems is therefore to find areas for dairy cow pastures.

The second priority is for land-use categories that have to be near the village (or settlements), such as corn and silage meadows. The location of these fields must respect three constraints: distance, soil (productivity) and slope.

The other land-use categories have a lower priority. There are no more constraints due to distance. The remaining constraints are soil and slope. The best soils are used for cereals. Finally, the hay meadow and heifer pastures are located in the remaining areas.

The preferences of the land-use categories were not taken into account until now.

\section{IMPLEMENTATION}

The model is implemented in two steps. The first consists in determining the homogeneous soiltechnical parcels of a territory, while the second consists in locating the various land-use categories of a farming system in this territory. Details of how homogeneous soil-technical parcels are determined are described in the section 4.1. We now describe how land-use categories are located in a territory. Until now this reasoning has been implemented for three farming systems which are LMI, LFR and LC. The parameters of all these farming systems are a number of dairy cows $\left(n_{\mathrm{C}}\right)$ and a surface of cash crops $\left(s_{\mathrm{CC}}\right)$.

As the farming system and the number of cows $\left(n_{\mathrm{C}}\right)$ are known, the number of heifers $\left(n_{\mathrm{H}}\right)$, steers ( $n_{\mathrm{S}}$, zero for the LMI and LC systems) or baby beefs ( $n_{\mathrm{B}}$, zero for the LFR system) can be calcu- lated. The quantity of each foodstuff $(Q(f))$ is then computed according to equation (1):

$$
Q(f)=\Sigma_{t \text { in }\{\mathrm{C}, \mathbf{H}, \mathrm{S}, \mathbf{B}\}} n_{t} \cdot A_{t}(f) \cdot D_{t}(f)
$$

$A_{t}(f)$ is the daily amount of the foodstuff $f$ for the animal type $t ; D_{t}(f)$ is its annual duration. These values are data up to now, but could be considered as parameters in the future (see sections 6.1 and 6.3).

The required surfaces for dairy cow pastures $\left(s_{\mathrm{CP}}\right)$, for heifer pastures $\left(s_{\mathrm{HP}}\right)$ and steer pastures $\left(s_{\mathrm{SP}}\right)$ are computed according to the possible types of meadows, their stocking rate, and the characteristics of the animals (UGB). For instance, there are intensive and extensive meadows (IM and EM, respectively) with different stocking rates ( $s r_{\mathrm{IM}}$ and $s r_{\text {EM }}$, respectively). The LMI systems use intensive meadows for dairy cow pastures [equation (2)] and extensive meadows for heifer pastures [equation (3)]:

$$
\begin{aligned}
& s_{C P}=n_{C} \cdot u g b_{C} / s r_{I M} \\
& s_{H P}=n_{H} \cdot u g b_{H} / s r_{E M}
\end{aligned}
$$

We now describe the main steps of the algorithm which was used to determine the location of landuse categories over a territory. The step order is the same as the farming system priority order (see section 4.2).

1) Location of the dairy cow pastures.

2) Corn location (for LMI and LC systems): the required surface is computed according to the required production of corn and the expected yield for the best soil class (TS). If there is not enough surface of this class of soil, the required surface is computed again from the remaining required production and for the other soil classes (with decreasing yields, see figure 3). The chosen parcels must respect the distance and slope constraints.

3) Location of cereal crops: the algorithm is the same as for corn location, except that distance constraints are different.

4) Location of cash crops (for LC systems): the required surface $\left(s_{\mathrm{CC}}\right)$ is located on parcels with the best soils according to the expected yields. These parcels must respect the distance and slope constraints. 


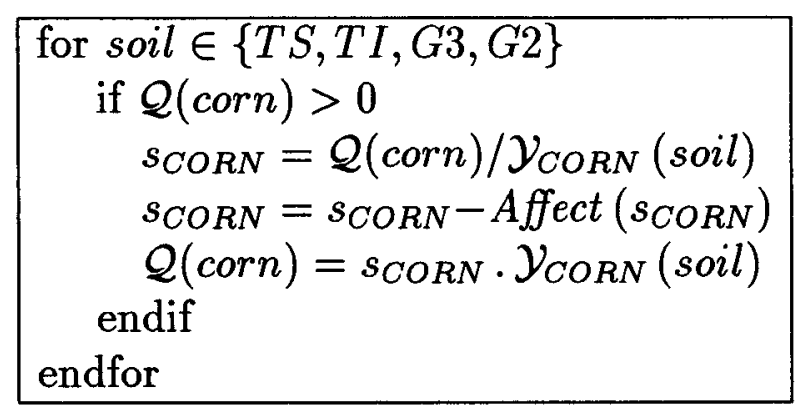

Figure 3. Algorithm for the allocation of corn surfaces: corn is the feedstuff and CORN is the crop. $Y_{C O R N}$ (soil) is a function giving the potential yield according to the soil. The function Affect achieves the allocation according to the constraints (soil, slope and distance); it returns the surface which has been allocated.

5) Location of hay meadows: the same algorithm as for corn location.

6) Location of heifer/steer pastures: they are located on the remaining areas (no constraint).

Allocating a particular land-use category on the territory is performed in the following way: the parcels are sorted according to their distance to the village. The first parcels to be examined are those with the smallest distance. If they correspond to the constraints and if they are not already occupied, they can be allocated to the current land-use category. This is performed until the required surface (or production) is reached. At the end, the surface or production can be greater than expected, since each parcel is entirely allocated to one land-use category. In our case, this problem did not occur (see section 6), since the surface of the parcels was generally rather small. In the future, the parcels will be cut during the computation to better fit the alloted surface (or production) to the required surface (or production).

\section{RESULTS AND DISCUSSION}

The algorithm was applied to data from the territory of Lignéville, on the Vittel Plateau (Vosges). The three systems were tested with various values of the parameters $n_{\mathrm{C}}$ and $s_{\mathrm{CC}}$. Using the first results, we developed options which are described in section 6.1. We then present a comparison of the model results for the LMI and LFR systems and a comparison between the model results for the LC system and field data.

\subsection{Model options}

The original model only takes into account annual land use. However, land use in real farming systems considers crop rotations or spatial associations (for instance, hay meadows are near pastures so that they can be used as pasture at the end of summer). We therefore added two new rules to the model. The first one concerns crop rotation, and the second one grazing pasture and hay meadow associations.

1) Corn and cereals (wheat or barley) are associated to form several kinds of rotations such as: corn-wheat, corn-corn-wheat-wheat, corn-corncorn-wheat-wheat-wheat, etc. We consider the 2-year rotation: wheat fields should also be convenient for corn (and vice versa). Since the constraints on corn are greater than the constraints on cereals, the algorithm allocates cereals to corn-convenient areas, with about the same surface as corn. During the computation corn is alloted at the same time as cereals.

2) In the LMI system, each cow needs 1 ha of pasture, which is divided into two parts during the season: the first part $(2 / 3 \mathrm{ha})$ is grazed from the beginning, while the second part is first cut, and then grazed. Distance is less of a constraint for this second part.

According to these rules we obtained the LMI system resulting map which is shown in figure 5 . Conversely, the map of figure 4 was drawn up for the original LMI system (no rotation, no spatial association). Comparing the two maps shows that the areas allocated to corn and cereals are quite similar. Moreover, the pasture circle in the map of figure 4 is surrounded by a circle of grazed hay meadow in the map of figure 5. In this particular example, including rotations had only a minor 
Figure 4. Map of land use for a LMI system model with 420 dairy cows, Lignéville territory, Vittel plateau. The areas which are not used are coloured black and the areas which are too small are in white.

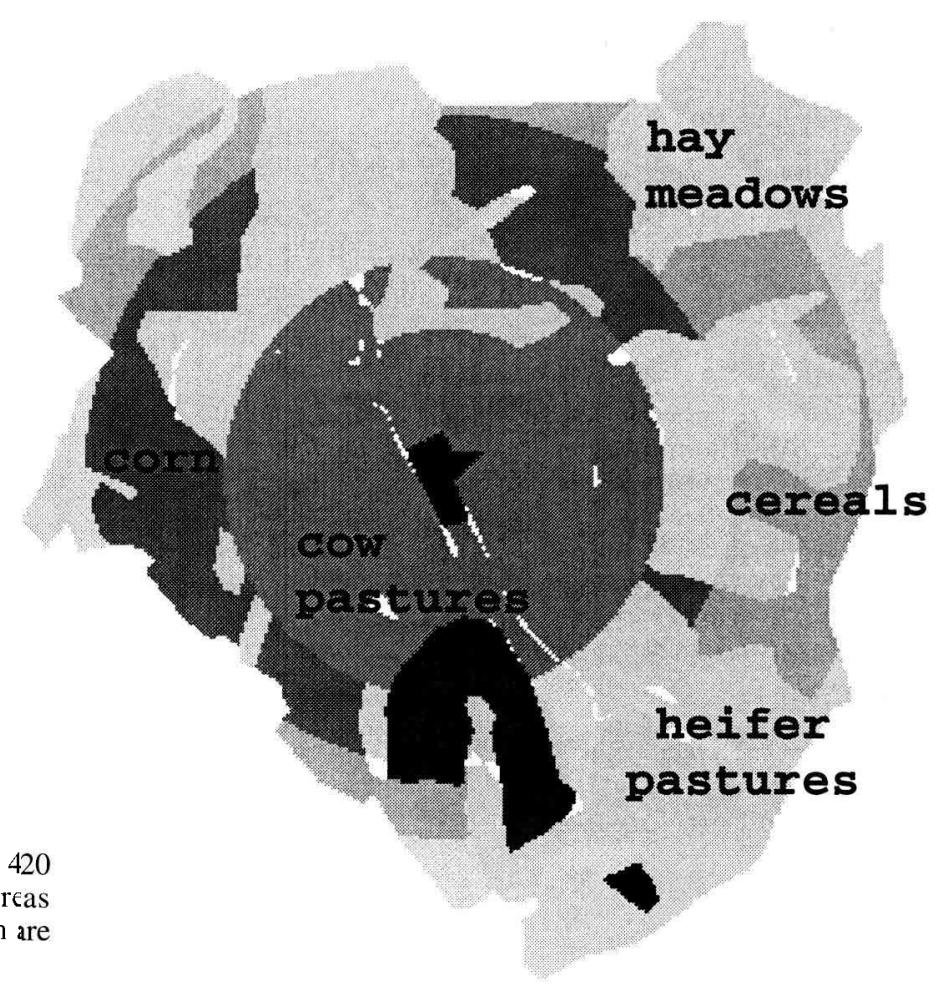

Figure 5. Map of land use for a LMI system model with 420 dairy cows, Lignéville territory, Vittel plateau. This particuler model includes rules about crop rotations and meadow associ-

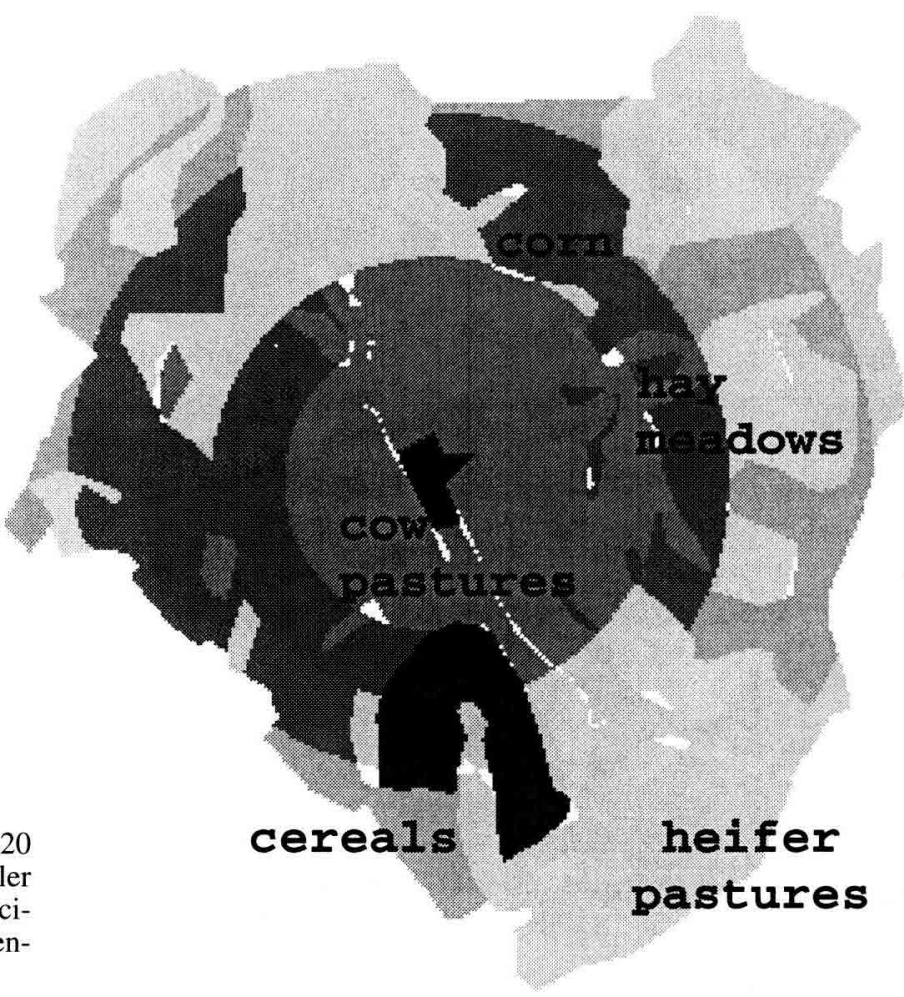
ations. Unlike the map in figure 4, there are cut-grazed intensive meadow which are coloured mid-grey. 
effect on the resulting map. However, in a territory where there is less available arable areas, the effect could be considerably greater.

Other options have been added to the model. For instance, food supply can include alfalfa and the heifers can graze on intensively managed meadows (see figure 8).

\subsection{Comparing LMI and LFR system models}

We now compare the resulting land-use maps for the two systems LMI and LFR with the same $n_{C}$ value (number of dairy cows). In the LMI system shown, cows are fed with corn only during the stable period (winter). This system is less intensive than the mean LMI system which has been described previously (section 3.2). We have chosen $n_{\mathrm{C}}=280$. For this number of dairy cows, the LFR system needs all the territory of Lignéville whereas the LMI system uses only $78 \%$ of this territory.
Taking into account the milk production of cows (which is $20 \%$ greater for the cows of LMI systems), the LMI system uses far less territory than the LFR system for the same milk production (quota). The parcels which are not alloted to the LMI system are generally outlying parcels or parcels with poor soil (see figure 6). The slope criterium does not play a role since the steeper slopes are located near the village: these parcels are all alloted to cow pastures.

Increasing the production per animal unit liberates areas and allows other production, such as cereals. For instance meat production was increased when it changed from steers to baby beef. Baby beefs are fed with corn and stay in a stable. The change to baby beef also liberates pasture areas. A baby beef needs 0.45 ha of corn for 18 months while a steer needs 1.5 ha of hay meadow and pasture for 26 months. The LFR system appears to be 'geophagic'. This can be tested by studying the recent surface growth of enterprises of this system type at a regional scale.

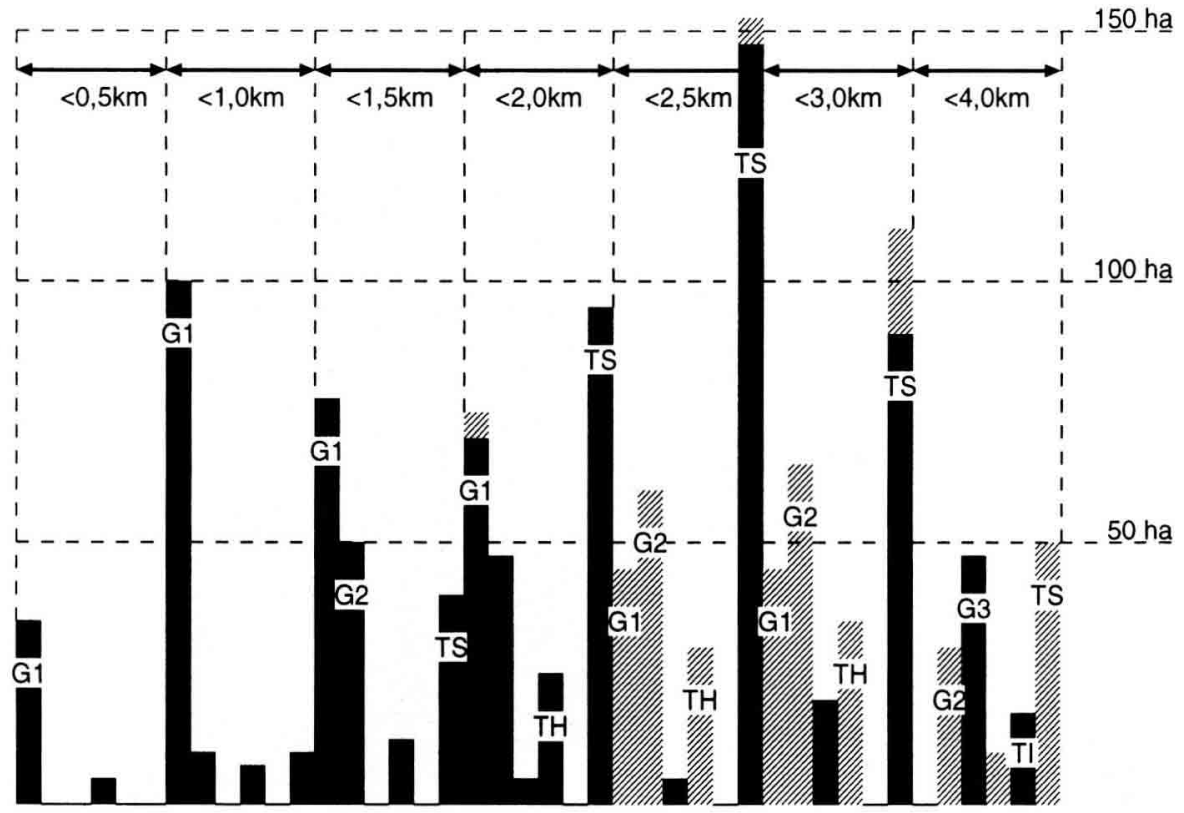

alloted surface 嫒non alloted surface
Figure 6. Histogram of the alloted and non-alloted areas according to the soil and distance criteria, for a LMI system model with 280 dairy cows, Lignéville territory, Vittel plateau. There are seven distance classes from $[0 ; 0.5[$ to $[3 ; 4[(\mathrm{~km})$. For each distance class, soils are sorted as following: G1, G2, G3, TH, TI, TS. 


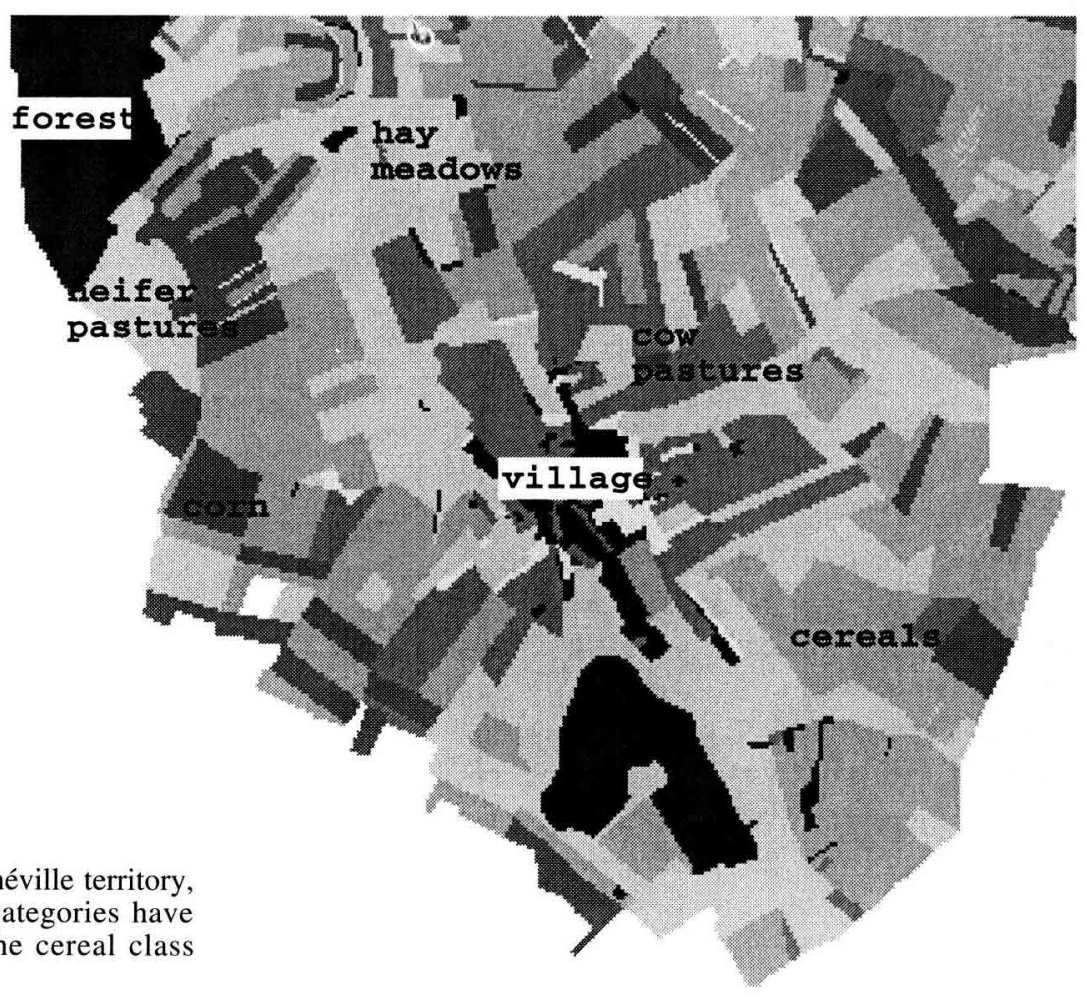

Figure 7. Field survey of land use on the Lignéville territory, Vittel plateau, 1990. The various land-use categories have been clustered into classes (in particular the cereal class includes rape).

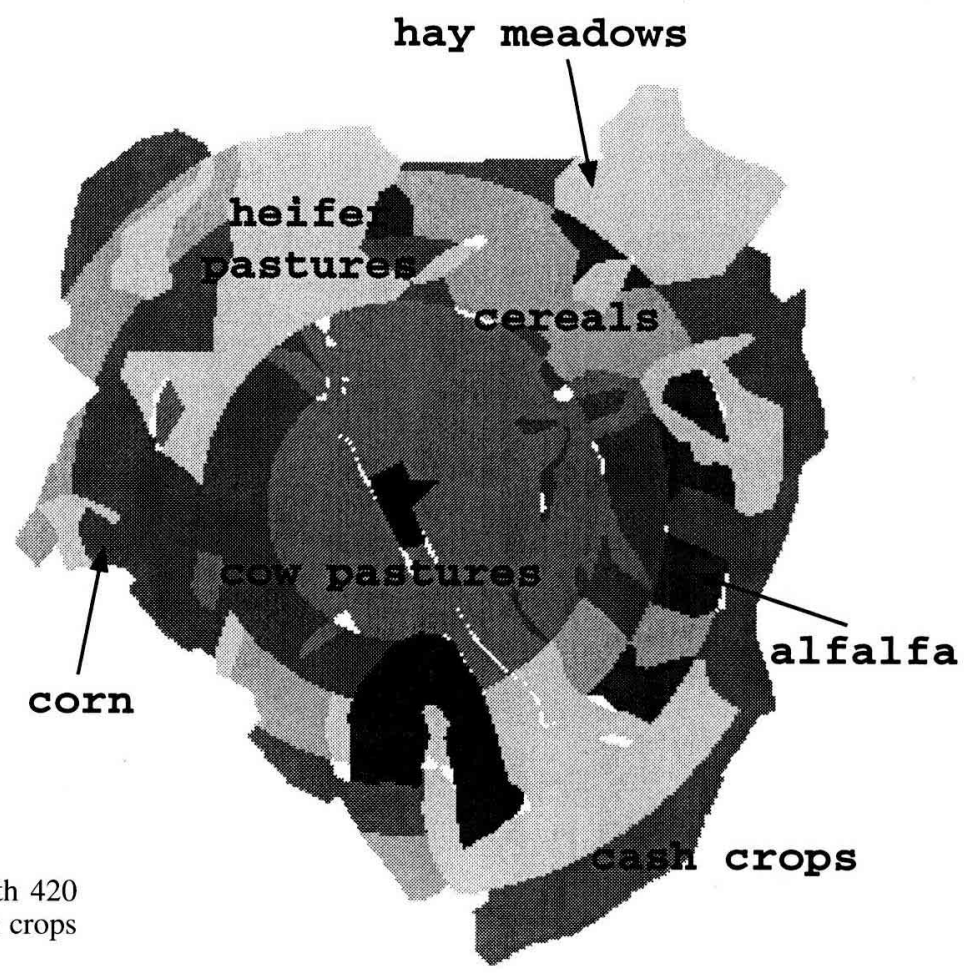

Figure 8. Map of land use for a LC system model with 420 are located on the borders of the village territory. 


\subsection{Comparing LC system model and field data}

Today, the territory of Lignéville is occupied mainly by LMI system enterprises (seven), which have a total of about 420 dairy cows. Field data have been collected for a few years [10]. An example is shown in figure 7: the distribution of agricultural land-uses is roughly $50 \%$ grassland (pasture and hay meadow) and $50 \%$ crops (rape, cereals and corn).

Since there are cash crops (rape) on the Lignéville territory we compare the field data with the results of the LC system model (figure 8). In this particular model heifers are fed on intensive pastures and feed supply includes alfalfa, so that meadow areas are reduced. The algorithm first computes and allots the areas which are required by the herd (corn, cereals and meadows). Then, it allots the remaining areas to cash crops (see section 5).

The difference between the two maps can be interpreted in two ways:

by evaluating the global surface differences;

by evaluating the local differences (per parcel).

The second method which requires pluri-annual data to be used, is in progress. Only a global evaluation can be given at present.

The resulting map of the LC system model is partitioned as follows: 800 ha of grassland (cow and heifer pastures, hay meadows, alfalfa), 500 ha of crops (corn, cereals for food supply, cash crops). Grassland occupies $60 \%$ of the territory while crops occupy only $40 \%$.

The number of cows and the available territory are the same, whereas the real system has a greater crop surface than the system model. This can be explained by two assumptions.

- The current systems are more intensive than the model. This means that the dairy cows are partially supplied with corn in the summer, so that the surface of pasture can be reduced. Conversely, the crop surface increases (more corn).
- The territory which is really used by the enterprises of Lignéville is underrated. This is possible, since Lignéville is near Vittel, where there are only two enterprises left. This assumption can be tested by a field survey.

These preliminary results are used to improve the rules of the model and improve the model itself by adding new rules. These new rules should particularly represent the variety of the kinds of farm systems. Nevertheless, we have to test our model with other territory examples.

\subsection{Discussion}

The purpose of the kolkhozian model is to describe the spatial organization of land use in farming territories according to the existing farming systems and their physical and technical constraints. We have described current farming systems. At present, we can test small changes in these systems (i.e. number of animals, animal feeding, new crops) and their effect on the land use at a regional scale. We did not represent economical rules or constraints either as an input or as an output of this model. This will be carried out in the future (see next section).

We assumed certain simplifications. A major one was that the farmers from a village used the whole territory of this village and only this territory: this was realistic until the last known statistical data in 1988. Since this date, farm size in Lorraine has increased and the farmers can go further thanks to new equipment: direct surveys have shown that farmers now have land outside of their village. This can also be demonstrated by the Kolkhozian model (see section 6.3) and should be taken into account in our model. Since we do not know which parcels belong to which farmers, we have to represent this phenomenon in a qualitative way: for instance we can define 'regressive' villages (where some parcels are used by farmers from other villages) and 'transgressive' villages (where farmers own parcels in other villages). We can then define 'regression' or 'transgression' rates for each village and randomly allocate parcels to inner or outer 
farmers, considering several villages in the same time. This requires significant modifications of our model (and its implementation) which shall be made in the future.

\section{CONCLUSION AND FUTURE WORKS}

First, we point out that this study was initiated during the development of a knowledge-based system. It is a part of the knowledge acquisition process and therefore it involves a cooperative model building process between the expert (the agronomist) and the knowledge engineer [9, 12]. Such processes have already been shown to be of interest to agricultural problems, as in Girard [11]. We have built up an explicit model of rules which were previously implicit or disparate. These rules concern farming systems, units, land use, etc. The modelling process is interesting in itself since it involves a discussion on the knowledge of the agronomist. Moreover, the model implementation and the first results obtained and compared with field data are useful for improving or correcting the rules as well as the knowledge of the agronomist.

In the future, the kolkhozian model will be developed in two ways. First, we will include farming systems other than LMI, LFR and LC. Second, we will include combinations of farming systems. This requires improving our knowledge about different farming systems sharing one territory.

Moreover, we will use our model on several village territories as soon as regional soil and slope maps become available. The maps of the villages, village territories and distances to villages, are drawn from satellite data of the Lorraine region [2, $13,14]$. A map of the location of the various farming system types will also be needed [16]. This map can then be used to forecast the variation in regional land use.

Our model can also be used for dynamic studies of regional land use and this is of major interest. We only have to add rules which concern this dynamic, for instance: land-use changes inside a farming system because of economical constraints; changes in the location of land-use categories because of technical improvment; changes in farming enterprises (switch from one farming system to another); some of them disappear, others increase their surface. The model can also include rules about pollution and erosion: new regulations or techniques. We intend to test the possible (or impossible) evolutions of land use, and not to optimize land use according to economic or other constraints.

Finally, similar models could be constructed in other regions where the characteristics of the settlements, territory and farming systems are different. This is another model building process which involves another expertise.

Acknowledgements: We thank F. Papy and J.P. Deffontaines for reviewing this paper. This study was supported by the Région Lorraine.

\section{REFERENCES}

[1] Auzet V., Boiffin J., Papy F., Maucorps J. and Ouvry J.-F., An approach to assessment of erosion forms and erosion risks on agricultural land in the northern Paris Basin, in: Boardman J., Foster I.D.L., Dearing J.A. (Eds.), Soil Erosion on Agricultural Land, John Wiley and Sons, New York, 1990, pp. 383-400.

[2] Bachacou J., Reconnaissance des occupations du sol sur images satellitaires à l'aide du système Aérosol, Technical Report, Lab. d'intelligence artificielle et de biométrie, Inra-Nancy, 15 p., 1995.

[3] Benoît M., La gestion territoriale des activités agricoles. L'exploitation et le village: deux échelles d'analyse en région d'élevage, thèse, Ina-PG, 1985.

[4] Benoît M., La gestion territoriale de l'activité agricole dans un village lorrain, Mappemonde (4) (1990) 15-17.

[5] Buick R.D., Stone N.D., Scheckler R.K., Roach J.W., CROPS: a whole-farm crop rotation planning system to implement sustainable agriculture, AI Applications 6, (3) (1992) 29-50.

[6] Deffontaines J.-P., Organisation spatiale de l'activité agricole et développement d'une petite région lorraine, Mappemonde (4) (1990) 12-14.

[7] Deffontaines J.-P., Du paysage comme moyen de connaissance de l'activité agricole à l'activité agricole 
comme moyen de production du paysage. L'agriculteur producteur de paysages. Un point de vue d'agronome, C. R. Acad. Agric. Fr. 82, (4) (1996) 57-69.

[8] Deffontaines J.-P., Benoît M., Brossier J., Chia E., Gras F., Roux M., Agriculture et qualité des eaux, diagnostic et propositions pour un périmètre de protection, Inra, Paris, 1993.

[9] Ford K.M., Bradshaw J.M., Adams-Webber J.R., Agnew N.M., Knowledge acquisition as a constructive modeling activity, Int. J. Intelligence Syst. 8 (1993) 9-32.

[10] Gaury F., Systèmes de culture et teneurs en nitrates des eaux souterraines : Dynamique passée et actuelle en région de polyculture élevage sur le périmètre d'un gîte hydrominéral, thèse, Ensa, Rennes, France, 1992.

[11] Girard N., Modéliser une représentation d'experts dans le champ de la gestion de l'exploitation agricole. Stratégies d'alimentation au pâturage des troupeaux ovins allaitants en région méditerranéenne, thèse, Université Claude-Bernard-Lyon-I, France, 1995.

[12] Krivine J.-P., David J.-M., L'acquisition des connaissances vue comme un processus de modélisation: méthodes et outils, Intellectica 12 (2) (1901) 9, 101-137.

[13] Le Ber F., Modélisation des connaissances et raisonnements pour l'analyse des paysages agraires à partir de données satellitaires, thèse, Université HenriPoincaré-Nancy-I, 1993.
[14] Mangelinck L., Le Ber F., Tabbone S., Deffontaines J.-P., Reconnaissance de paysages modèles sur images satellitaires, in: Christophe C., Lardon S., Monestiez P. (éd), Colloque Étude des phénomènes spatiaux en agriculture, Inra, Paris, 1995, pp. 33-45.

[15] Maxime F., Mollet J.-M., Papy F., Aide au raisonnement de l'assolement en grande culture, Cahiers Agricultures 4 (1995) 351-362.

[16] Mignolet C., Projection spatiale de la diversité des exploitations agricoles du département des Vosges, in: Christophe C., Lardon S., Monestiez P. (éd), Colloque Étude des phénomènes spatiaux en agriculture, Inra, Paris, 1995, pp. 143-150.

[17] Morlon P., Benoît M., Étude méthodologique d'un parcellaire d'exploitation agricole en tant que système, Agronomie 6 (1990) 499-508.

[18] Perrot C., Typologie d'exploitations construite à dire d'experts. Proposition méthodologique et premiers résultats obtenus en Haute Marne, Prod. Anim. 3, (1) (1990) 54-66.

[19] Pierret P., Activité agricole, organisation de l'espace rural et production de paysage. Une démarche de modélisation multi-échelle testée dans le département de la Haute-Marne, thèse, Université de Bourgogne, France, 1996.

[20] Stone N.D., Buick R.D., Roach J.W., Scheckler R.K., Rupani R., The planning problem in agriculture: Farm-level crop rotation planning as an example, AI Applications 6, (1) (1992) 59-75. 